\title{
Meta
}

Journal des traducteurs

Translators' Journal

\section{Translating "Nation" into Japanese during the Modernization of Japan: Dynamics of Translation as a Social and Interactional Practice}

\section{Mino Saito et Mutsuko Tsuboi}

Volume 60, numéro 2, août 2015

$60^{\mathrm{e}}$ anniversaire. Les horizons de la traduction : retour vers le futur

$60^{\text {th }}$ Anniversary. Translation's Horizons: Back to the Future

60mo aniversario. Los horizontes de la traducción: regreso al futuro

URI : https://id.erudit.org/iderudit/1032920ar

DOI : https://doi.org/10.7202/1032920ar

Aller au sommaire du numéro

Éditeur(s)

Les Presses de l’Université de Montréal

ISSN

0026-0452 (imprimé)

1492-1421 (numérique)

Découvrir la revue

Citer ce document

Saito, M. \& Tsuboi, M. (2015). Translating "Nation” into Japanese during the

Modernization of Japan: Dynamics of Translation as a Social and Interactional

Practice. Meta, 60(2), 369-369. https://doi.org/10.7202/1032920ar 


\title{
Translating "Nation" into Japanese during the Modernization of Japan: Dynamics of Translation as a Social and Interactional Practice
}

\author{
Mino Saito and Mutsuko Tsuboi \\ Rikkyo University, Tokyo, Japan / Juntendo University, Tokyo, Japan \\ tsuboi@rikkyo.ac.jp / mi-saito@juntendo.ac.jp
}

This paper focuses on the translation of the term "nation" into Japanese during the Meiji era (1868-1912), drawing on the framework of sociosemiotic anthropology that explores the dynamics of translation practice as an interaction occurring in sociocultural and historical contexts. The discussion revisits the roles played by translation in the modernization of Japan.

During the late 20th century, in an increasingly globalized world, Western scholars, including Benedict Anderson and Ernest Gellner, criticized the terms "nation" or "nation state" as historical constructs of modernization. However, in Japan, the discussion regarding the notion of "nation" always leads to an inevitable problem. In Japanese, there is no single word that can represent the Western concept of "nation." There are mainly two translations of "nation": kokumin and minzoku. Both terms were kanji compounds created by either borrowing a word of Chinese origin or combining two kanji, as was done with many other translated words in the early Meiji era. These two terms have coexisted and competed provoking significant confusion in academic fields and translation practices. The problem has usually been attributed to the impossibility of translating between different cultures or to translator's incompetence. Thus, the dynamics of translation as a social practice barely receive any attention.

This study aims at clarifying the reasons behind the repeated occurrence of such confusion, and shows that while kokumin was adopted to express the English or French concept of "nation" at the predawn of Japan's modernization, minzoku - representing the German Volk - appeared in the middle of the Meiji era. Moreover, both translations and their acceptance by people blended with the political, ideological, sociocultural, and historical elements that surrounded translation in this period. Japan's increasing interest in the territorial expansion in East Asia and its simultaneous struggle to unify the Japanese people as kokumin were crucial aspects of Japan's sociocultural and historical context in this period.

Mutsuko Tsuboi is associate professor of translation studies at the Rikkyo Graduate School of Intercultural Communication, Japan. She received a PhD in intercultural communication studies from Rikkyo University (2011). She specializes in translation studies and linguistic anthropology. Her recent works include Bosunia-funso hodo: Media no hyosho to hon-yaku koi (News reports of the Bosnian conflict: Media representation and translational act) (2013). Mino Saito is currently an assistant professor at the Faculty of International Liberal Arts, Juntendo University, Japan. She has a Ph.D in intercultural communication studies from Rikkyo Univeristy, Japan (2011). Her latest article, 'The power of translated literature in Japan: The introduction of new expressions through translation in the Meiji Era (1868-1912)' will presently be published in Perspectives: Studies in Translatology. 